\title{
Self-concept in Western Philosophical Tradition
}

\author{
Ruimin Li \\ School of Humanities \\ Tsinghua University \\ Beijing, China
}

\begin{abstract}
Self-concept has a complex transformation in the history of philosophy. Through the investigation of this transformation, we can see how the philosophy of different eras internalizes into the concept of life. In modern times, subjective philosophy experiences the process of rise, establishment, and rethinking, denial, and even rebellion, in view of different philosophers, self has different faces and carries different values. Combing their differences, you can see a new tendency, which is a new subjective concept - the self of the others - the possibility of birth.
\end{abstract}

\section{Keywords—self; subject; others; freedom}

\section{INTRODUCTION}

The Self-concept has a complex transformation in the history of philosophy. From Socrates' "knowing yourself" to Descartes' "I think, therefore I exist", the position of self in philosophy cannot be underestimated. By examining this transformation, we can see how does the philosophy of different eras internalize into the concept of life and exert its influence. In modern times, the self has become the subject of philosophy. The subjective philosophy has also experienced the process of rise, establishment, and rethinking, denial, and even rebellion. In different philosophers, self has different faces and carries different values. Combining the understanding of self with the concept of "subjectivity", we can see some new tendencies in contemporary philosophy, such as Levinas' "self for others" is a brand new subjective concept.

\section{THE SELF-CONCEPT IN THE ClASSICAL PERIOD AND THE SELF-CONCEPT IN MEDIEVAL PHILOSOPHY}

Philosophy has an old maxim "knowing yourself". Starting from this maxim, Western philosophy can be said to always on the road of pursuing self. Whether seeking truth or seeking good or even seeking beauty, we must not forget to "seek ourselves" - self is not only the starting point of understanding, but also the starting point of the relationship with others, it is the basis for the possibility that the world can be presented. In the two poles of the self and the world, the self is always closer to philosophy, because only in self, the world can be presented.

Let us start from ancient Greece. Both in the Homer epic and in the Greek tragedy, the self and the characters are often solidified together. It can be said that in classical civilization and earlier civilizations, the concept of self is still in a chaotic stage that has not been highlighted. If we think of Achilles, we will always think of him as a hero in the Trojan War, the son of the ocean goddess Thetis and the hero Peleus; and when we think of Oedipus, we will immediately think of the king of Thebe in Greek mythology, the son of Laios. Their roles are their identities, and their characters, like the property of their characters, are accompanied by their behaviors, and finally outline the trajectory of their actions and are completed in their destinies. Different from the character is the destiny said by modern people, for the ancients, the destiny is action, action is character. To put it succinctly, it is not the character that shapes the destiny, but the fate that cannot be captured gives people different characters.

This may be due to the fact that there is already an awakening in the muddled consciousness of the simple people, recognizing that living in the community and taking up their own responsibilities in the community is the trait that only belongs to human beings, and is a sign that is different from the original state of obscurity. When Plato focused on a possible ideal city, when Aristotle said that man is a social animal, they must talk about this.

Greek philosophy began with the search for the origin. At the beginning of the search, the object/element was considered as the origin. However, after the transforming of Parmenides to Plato, the basic proposition of philosophy was also changed. Heraclitus, who was at the same time as Parmenides, had a saying, let us seek logos. He also said that this logos is one, is everything, and something that everyone shares and hides in everyone. For example, "thought is the greatest advantage, wisdom lies in telling the truth and acting in accordance with nature, listening to the nature". ${ }^{1}$ (P6) Also said, "Ideology is shared by everyone". 1 (P6) Parmenides also emphasized logos, but he was more focused on the need for everyone to use their logos to judge and act. For example, "You should learn all kinds of things, from the solid core of perfect truth to the opinions of ordinary people who do not contain true feelings. Although the opinions are not true, you still have to experience them, because you could only make the judgment for the fakes through thoroughly and comprehensive study". 1 (P11) And Socrates said that "Unexamined life is not worth to live". If for Heraclitus, logos is rational understanding of the inevitability of nature, and for Parmenides, logos already has the intellectual connotation of self-examine although subject to external necessity. The examination here is request for their own independent

Plato et al:: "Basic Documents of Western Philosophy", translated by Bao Limin, etc. Hangzhou: Zhejiang University Press, 2007, P. 9. 
reflection, but the things this reflection rely on and the content of this reflection is still something that we have in common. Similarly, in Socrates' view, the debate as a part of public life is also to better inspire you to know yourself and to discipline yourself to listen to rational teaching. The source of reason is the trusted god's will, and the things shared by logos and others that everyone can trust. It can be said that self/individuality at this time is annihilated in universality.

Plato's theory of ideas regards the universality of ideas as the greatest connotation of the word "essence". It is intended to make the individual existence in rheology find its basis and foundation in the relationship with the invariant ontological existence so that it can be recognized and grasped. The ideas are eternal, my understanding of all things stems from the cognition of ideas; the understanding of ideas is the true knowledge; this kind of true knowledge is obtained through memories. However, whether it is possible to obtain a conceptual understanding depends on luck and fate, and the fight is the "high and low level". Although "I", as the selfevident basis of understanding, has not been given any special authority, compared to "us". It can be said that "I" is equivalent to "us" in most of the time. "Idea" is like the concept of entity used in later philosophy, it is the object of understanding and the basis of commonality. However, in any case, from the natural chaotic me, or the chaotic non-self stage to Plato's philosophy, it has initially included the distinction between me and the object, and how I should observe the reflective consciousness of the object of understanding. This process is also a process in which selfawareness is reflected. Observing has a perspective, and any knowledge for observation is inevitably with a perspective, perspective means bias. However, the theory of ideas is full of impulses to avoid the limitation of perspective. Plato believes that the idea can achieve absolute recognition as a reality above reality. Thus, Greek philosophy laid the foundation for the pursuit of a kind of knowledge without a perspective at the beginning, or knowledge with full perspective, and the theory of ideas is the beginning of this pursuit. This pursuit of nonperspective knowledge has brought us science. It can be said that philosophical misunderstanding has breed science.

In Aristotle, the situation has changed. His questioning changed from "what is this" to "why this is this", and this change has inadvertently improved the status of the individual, and this one/individual becomes an entity. The status that has been improved is the individual object, not the individual me. In classical philosophy, "I" still expresses "us", especially in theoretical philosophy, "I" is equivalent to "us". The reflection on me is more in practical philosophy, my relationship with others, with the collective. In this sense, "Republic" is to explore how different me can become the best of us in a reasonable way. "Ethika Nikomachea" discusses how individual me live a good life successfully in a community through reflection.

In classical philosophy, there is a non-reflective plain cognition of self. This is because philosophy is still amazed by the glare of the outside world in its childhood, and the surprise of object is more than the surprise of its own. As a window to understand the world, I am a universal window, one of the many unknown windows that existed, what I experienced, is what we can experience. In short, in classical philosophy, it is better to say "know ourselves" than to "know yourself", and how we can spend this life meaningfully in the community through effort, the goodness of the community is one of the evidences of my personal good life. However in this way, there are some disadvantages for only seeing part of the picture, because in the philosophy of the Hellenistic period, such as scepticism, Stoic school and other philosophies are not exactly the same. The concept of relativism contained in scepticism can be regarded as a pursuit of individual freedom. This is also a basis for scepticism to serve as a post-modern intellectual resource. But as a general tendency, make self equal to us is the common thought that ancient philosophy, even ancient ideas have. A clear outline of this tendency can be seen in McIntyre's book "Pursuing Virtue".

As a master of the godfather philosophy, Augustine has excellent insights into the thinking about the self issue. I face God as an individual, God and I are the encounter of me and you (although it is an asymmetrical encounter). I need to confess guilty, this confession can only face the only one God, no intermediary. Free will is the earliest and clearly proposed by Augustine. Because of the free will so it has the ability to make mistakes, I need confession if I make mistakes. When Augustine suggested that I was the existent of free will, the concept of self was also highlighted as never before. Self is set out from us, from social relations, from the role identity. But the self that Augustine refers to is the grace of God, and the free will is to some extent a product of God's grace too.

The Christian faith has a direct relationship with the birth and maturity of self-concept. Due to the Christian monotheistic faith requirements, the supreme infinity of God is emphasized, the relationship between human and god emerges as the basic relationship before the relationship of the individuals, and the individuality can be extracted from the community of human beings. In the presence of God, the uniqueness of man is also emphasized, and his free will is responsible for his actions. Everyone is first God's people, and then they have their role in the human world. The self gradually gained a higher status than its role identity, and eventually became the subject in modern philosophy.

In addition, the dichotomy between the soul and the body emphasized in Christianity is also a potential preparation for the prominence of self-concept. The soul is an existence which is independent of the body, this undoubtedly enables one to think about the existence of self from the relationship which beyond blood relatives, and no longer stubborn in the relationship world that is immersed in from birth and cannot extricate themselves. And because the soul is higher than the body, and will eventually face the final judgment alone, so that force people to constantly review them and constantly reflect on their own behavior. And it is especially important that this reflection is carried out independently within the self, because the forgiveness to be obtained comes from God, not from any ruler in the world. If this reflection presupposes the presence of any interlocutor, it can only be the only God - an eternal, safe presence, who can prepare for the opening of the self. Confession can also be a kind of confiding, or it can also be a redemption or a gratitude. This can also be proved in 
European literary works, the inner description of the characters is always parallel to external actions, and even more prominent, this is the inevitable legacy of confession literature. This is different from the expression of the East, and it is obviously different from the form of ancient Greek tragedies. Both of them mainly express the characters by depicting external actions, even if they express their inner feelings, they often use delicate psychological monologues with caution.

Of course, the church as an intermediary always uses its own means to participate in the communication between the believers and God, but Christianity has contributed to the germination of the individual's self-consciousness, that is for sure. In general, individuality was suppressed by the church in the Middle Ages, but the free will theory, the dichotomy between the soul and the body, the final judgment and so on, all contributed to the constant emergence of self-concept.

\section{SELF AS THE SUBJECT}

After the long Middle Ages, the Enlightenment brought a sudden renewal and development of self-concept. The new philosophy and the scientific concepts and self-concepts bred in philosophy complement each other and reflect each other. With the appearance of Descartes philosophy, the self becomes the subject and officially rises to the throne of philosophy.

Descartes brought the subjective turn of philosophy. This turn was mainly to establish the individual, the first person, as the subject. The establishment of the status of individual I is regarded as both the source of knowledge and a well-deserved source of value. The self-clarity of "I think" has both the tendency of solipsism and also the foundation of the distinction between self and world duality.

"I think" has established the subjective concept of epistemology and appearance. The self has become synonymous with self-consciousness to a considerable extent and has become a self-evident subject. Such a subject of consciousness means that freedom is its highest pursuit. However, the true establishment and strengthening of the subjective philosophy are due to the strong intellectual pursuit which is the foundation of scientific knowledge in modern times. Subjectivity philosophy is dualism in nature, even when dealing with practical issues, such as ethical issues. This foundation is constantly being strengthened in the predicament of epistemology itself and in the legacy of Plato's philosophy. "Plato's ethics has always been a strict dualist ethics." ${ }^{2}$ (P148) It should be emphasized here that this subject not only lays the foundation for knowledge, but also lays the foundation for value, it is the subject that carries the truth of knowledge and the goodness of morality. However, Descartes and the philosophy after Descartes have always encountered problems in the demonstration for absolute freedom. There is no absolute freedom, so there is no absolute responsibility. The limit of freedom is the paradox of freedom.

[GR] E.Zeller, Translated by Weng Shaojun. History Outline of Ancient Greek Philosophy. [M]. Jinan: Shandong People's Publishing Press, 1996
Descartes' "I think" actually presupposes a self-concept with identity. This self is behind all living thinking activities and can be clearly perceived by me, it is the most coherent base of all conscious activities. Not only perceive and recognize activities, but all emotional experiences, such as worry, curiosity, fear, anxiety, and hope, all occur on this foundation. The continuity of self-awareness gives self identity, and its identity also proves its continuity, the two rely on each other. In this way, "I think" is actually distinguishing the self from the non-self. The self and non-self division is the difference between the subject and the object. The dualist thinking of the subject and the object is thus firmly established as the classical thinking mode of modern philosophy. Self is free, outside the object world, it is the source of free action (including cognitive activities), and it is also the value bearer of moral behavior -in the big world, only the self is free, and the only carrier of moral realization.

Hume refuted Descartes' I think with his "no me theory". This refutation can also be seen as part of the difference between rationalism and empiricism. In Hume's view, in addition to impressions and perceptions, there is no other thing in the mind, hate, love, thinking, touch, and sight: all this is just perception. From Hume's view, we have no way of understanding what is the soul, let alone the continuous, constant self that is presupposed as the source of freedom. From a thorough empirical perspective, I am just a "perceived group" locked into the perception flow.

In empiricism philosophy, the soul is nothing but made of impression and perception. The agglomeration of the heterogeneous experience that begins with the impression segment ultimately constitutes the soul. From this point of view, the problem of others is just my experience of others experience only, up to the regular experience which is the level of understanding, but will not become the influence or hindrance to my behavior or action, that is, the problem of others is always in the category of epistemology. In empiricism philosophy, it always pay more attention to the cognition of others' soul. How can we know that others have a soul that is similar to mine? Empiricism philosophy and today's analytic philosophy mostly use inductive argumentation as the main method. Around this issue, many meaningful philosophical factions, such as spiritual philosophy, have been formed. However, for analytic philosophy, especially the soul and body issues explored by spiritual philosophy are basically not involved here. This is not based on the difference between rationalism and empiricism, but the philosophy and philosophers involved in the main former Levinas philosophy as the main dialogue object, and only among the former, the revolutionary nature of Levinas philosophy can be properly understood and properly evaluated.

Under the constant challenge of empiricism, the subjectivity philosophy is constantly improving. For Descartes, although the self still takes I think as the basic symbol, it is still a living experienced body. But for Kant, the self is more of the subject of logic, the subject of representation, and the inevitable accompanying object of all representational activities. 
It can also be found that from Descartes and Kant, the thinking of philosophy to the self has an invisible reversal, that is, from the universal to think about the individual into from the individual to think about the universal. Then the value of the individual/self has been raised, and the enlightenment spirit of self-determination and self-discipline becomes the mainstream value orientation. The self-concept in the context of enlightenment comes from the victory of subjective philosophy. The high-spirited subject concept began to regard "self is free" as an obvious fact. Self is free, because self is self-sufficient; the exploration of the world's primitives and the reflection of self became one, the self is the primitive, at least is one of the primitive.

The problem of others is also hidden in the self when the spirit of enlightenment is high. Self is the foundation of knowing the world. Only when I am within the self, I am selfevident and so can I be given trusted knowledge, besides self is all external and the others are the same. Others are my object of understanding belongs to the existence of the external object world, no matter how similar I am to him by observation, I can't know the true existence of others as I know myself, let alone his thoughts.

Kant continued Descartes' thinking, and he paid more attention to the demonstration of free will. Free will is not only the driving force of human actions, but more importantly, it is the only reason why people can break through the laws of nature and act without causing causality in the phenomenal world. Kant successfully proved the reality of ethical metaphysics, thus refuting the metaphysics of epistemology, or knowing the primacy of metaphysics. This is a revolution in the history of metaphysics, and it is a milestone that the ethical/practical activities reached the throne of metaphysics. However, Kant's philosophy is still an authentic dualistic philosophy, because the overall metaphysical effort constructed by theoretical rationality and practical rationality is based on the presupposition of the existence of God and the immortality of the soul.

The efforts that Kant tried to communicate the practical philosophy with metaphysical proves that people not only are the cognitive subject, but the more important identity is ethical subject. It has also received continuous attention in the German concept philosophy after Kant. Fichte, Schelling, and Hegel were all trying to overcome Kant's dualism, trying to prove that pure practical rationality itself is practicable, and pure practice itself is metaphysical. The self which gained great encouragement and manifestation will inevitably promote the principle of individualization, and the respect for the principle of individualization must also inherently contain respect for the individuality/uniqueness of others, otherwise the respect for self will become the synonym of selfish. The reason why Kant always considered people as a purpose not a tool is here. Universal humanity, I am us, I am also the only one of us, because I am unique, so I envision others' speciality.

\section{REBELLION AND REBIRTH OF THE SUBJECT}

Although the strict word "modern" can be traced back to medieval scholastic theology, we use the term "modernity" more often to describe the philosophical context and era which dominated by the progress concept towards the future since the Enlightenment. Modernity brings all kinds of philosophical ideas emerging, bursting and inevitably interacting and opposing each other, which undoubtedly brings the renewal of self-concept. We are still living in the influence of modernity, although we have invented the postmodernism to distinguish it from the era of rationality and freedom advocated by the Enlightenment, but postmodernism is more like a variation of modernity than a new era with a fundamental distinction between with modern.

Reflections on the self include reflection on the subjective philosophy in any case, or reflection on the self is an indispensable part of the reflection of the subjective philosophy itself. Moreover, the reflection on the self has also been reflected in modern and contemporary philosophy. The state hidden in many theoretical philosophies in classical philosophy has become a more direct reflection, and selfresearch has become an organic part of philosophical research. However, in modern and contemporary philosophy, the reflection of self is based on the denial and rebellion of its subjectivity. The reflection on subjectivity philosophy has brought about the denial of subjectivity. This denial is multiangled, continuous, and in-depth. At first, this phenomenon was regarded as a rebellion against the subject. With the continuation of time and the deepening of this rebellion, it showed more of a new birth of the subject.

Hegel's philosophy brought the subject to a new height of omnipotence, which in turn led to questions and reflections on the subjective philosophy. The reflection on Hegel's absolute subject and absolute spirit makes the subject no longer affirmed as in the Enlightenment period, and even the concern that the subject is too inflated has appeared. Husserl's concept of transcendental self and intersubjectivity is one of the reflections. Husserl once said that the transcendental self is suspending all presuppositions (including natural attitudes) to cut into the self-giving nature, only the ones directly given in consciousness are recognized by self-giving. In the end, Husserl learned that the transcendental self has the ability of perceptual intuition and category intuition. The former perceives the perceptual material, and the latter finally presents the object in a constitutive way. This transcendental self is more abstract and empty than Descartes' I think, and the feeling and emotional experiences are all suspended here as non-essential objects. In his later years, Husserl saw the danger that the transcendental self may caused other things and others to become self-conscious objects, so he proposed the concept of intersubjectivity. Through the ability of synaesthesia, it is acknowledged that others are the same subjective existence as me, not a purely conscious object. Others are independent of me, so my restoration of others is always not thorough. This reminds us of Leibniz's monadism. Leibniz believes that there is no window between the monad, but they are harmonious, this harmony is established harmony. Despite the intersubjective compensation, it is still impossible to deny that the transcendental self theory has a tendency of solipsism, even a new peak of solipsism, that is, the self as the source of meaning for all. 
Heidegger proposed Being-with-others. Being together is the essential way of existence of Dasein, and Dasein can only become common Dasein when it is being together. Being together is a feature and style of Dasein. Heidegger's Dasein has real and depravity two existence ways, Dasein which being together with others is often in the depravity state, the real self exists in the face of death and live toward death. Although depravity does not have any derogatory meaning here, even it is inevitable, because Dasein can not always be in the real state. However, it can still be seen that Heidegger regards the real self, the fearless self live toward death, as a more authentic and more affirmative way of existence. Beingwith-others is actually linked by coexisting with others. Existence is the bond that connects different daseins. Heidegger's self is a more practical self compared with Husserl's self, and was thrown into the world from the beginning. However, Dasein realized the existence through the true existence, the self is ultimately in loneliness, and even eventually can only admit that each self can only be a persecutor forever alone. Each self designs its own life according to its true understanding, Dasein community with the same goal/belief practices its destiny according to its true nature, in Heidegger's view, this is the meaning of being together. From understanding to the true self to the true community, from me to us, Heidegger's being together still has no place for others. Self, as long as we make true planning, we are already living in an ethical realm. The so-called ethics is to abide by the authenticity of existence. Perhaps after seeing this, Levinas resolutely began his own path of philosophical exploration which is completely different with Heidegger.

There are also reflections on subjectivity philosophy from the perspective of religious philosophy. According to the Jewish religious philosopher M. Buber (1878-1966), the subjective philosophy has always been stubborn in the distinction between subject and object, and seen the world from the relationship between I and it. The relationship of I-It is a philosophy that considers it/he as an object. This philosophy always carries out materialized thinking, especially alienating others. The real relationship is me - you, my face-to-face relationship with you is the attitude towards others. "All real life is an encounter". ${ }^{3}$ (P14) Of course, this is not a simple change of personal pronouns, but a change in attitude, or it may saying you but in fact meaning him, or to treat other object as you with divinity. Just as called God with you, every person who has divinity must be called by you, because you share the divine nature of God, and you for me also have the meaning that can't be understood by my knowledge.

Marx's philosophy is of course a kind of rebellion against the subjective philosophy. From the perspective of labor, he proposed practice is the essence of self, and the laboreconomic relationship is the decisive relationship. Later, Habermas also proposed the Communication Theory, the Intersubjectivity Theory, etc., all of which are a continuation and deepening of this rebellion. Bergson and Sartre's

[German] Martin Buber, translated by Chen Weigang. Meand you. [M]. Beijing: The Commercial Press, 2015. philosophy are the same. One of the core concepts of Bergson's philosophy is "continuation", which is a representation of the nature of time, and also a representation of the way the self exists. Bergson believes that the spacial imagination of time is the biggest misunderstanding of time. The spatialization of time has a tendency to look at time as a ready-made thing. In the concept of time that is understood by spatialization, time has a direction and a trajectory, the past, present, and future are like the coordinates of time. However, the real time is the constant emergence and continual annihilation. It is not appropriate to describe it with running water, because it is continuation is a pure stream without content; it is never interrupted and has no separability, just like self as an uninterrupted flow behind consciousness. The self is only free and creative as a continuation. "In fact, it is the whole soul that causes people to make free decisions. There is a dynamic series that is associated with movements; the more this series represents the basic self, the freer the movements are". (P113-114) The concept of continuation at first is the clarification of the free nature of self, but the connotation of "continuation" lies in the continuous change, which already has qualitative distinction with Descartes' I think and the meaningful subject of I think. Sartre's philosophy is also a kind of rebellion against the subject. Sartre realized that the freest subject is actually not free. Freedom is both a crown and an eternal bondage. The moment when I began to realize others existed, my freedom has already been threatened, for the same reason, I am also the terminator of his freedom to others.. However, it is not people choose freedom, but people are in choice all the time. For their choice, it is the freedom of the self and also the responsibility of self to themselves. Although freedom is rare, it has to be free, but freedom is like a burden. The subject from Hegelian omnipotence to Sartre's "have to", is like an intriguing turn.

In contemporary philosophy, the study of self/subject involves theoretical philosophy as well as practical philosophy. The possibility of knowing self and how to recognize self is often studied in epistemology and spiritual philosophy, and weather the self identity exist, the basis of self-identification, and how does the self be the same in action, how does different self communicate (intersubjectivity) such problems are often studied as ethical issues (practical philosophy).

Rebellion against the subject is a contemporary philosophical trend of thought. The opposition to the subject of power and the opposition to the philosophy of identity are organically linked together. The philosophy of Foucault, Deleuze, and Ricoeur are the representative of this trend of thought. In this rebellious camp, many people regard Levinas as the man in the same line, but Levinas clearly stated in the preface of his important book "Totality and Infinity" that his book is the defence of subject. A new subject is a new concept of self, which already exists at the beginning of Levinas philosophical path.

[French] Bergson, translated by Wu Shidong. Time and Free Will. [M]. Beijing: The Commercial Press, 1958. 
The self we are discussing here is more from the perspective of practical philosophy, that is, from the perspective of the relationship between self and others. Exploring the self from the relationship with others is an important theme of Levinas's philosophy. However, the relationship with others in Levinas is not entirely belongs to practical philosophy, that is, it is not subordinate to existentialism in traditional philosophy, practical philosophy is not a second-order philosophy, but is metaphysics, which is the first philosophy. Levinas defined self as a separate independent individual, and this kind of individual is an nonreducible absolute. Similarly, others separated from me are also absolute existence, absolute other, absolutely other people that cannot be penetrated by the light of my consciousness. This inner self is no different from Descartes' self from first look. The breakthrough lies in the fact that the formation of this separate self is driven by the emergence of others. That is to say, others are the real beginning of the self, and the self begins with the nameless existence, but the self at that time is not the true self. For Levinas, the others' issue is not an ontology-epistemy issue, but an ethical metaphysics. The purpose of discussing other people's issue is not how to recognize others' possible issues or how my freedom can face other people's issue, but it is directly the issue of how my responsibility to others is possible.

In the philosophical tradition, the issue of freedom and responsibility are often linked together. My responsibility stems from my freedom, just because I have freedom, so I can take my responsibility. It is also in this sense that Heidegger said in "The Essence of Freedom" that "Although the dominant issue is the issue of existence, the fundamental issue of philosophy is freedom". It can be said that the freedom issue is the ultimate focus of ontology in Heidegger. However, the absolute nature of the subject and the freedom of subjective existence are deeply bothered by others. Since I can't get the knowledge of others as I reflect on myself, others are reticent present to me, and they are the most reticent thing in all reticent existences. Sartre's "others are hell" is an accurate description of this situation. In Kant's philosophy, self means freedom, and freedom means free will. It is like, in Descartes, self means I think, and in Heidegger, self is Dasein, and in Levinas, the first meaning of self is "I am here!" ${ }^{\text {(P119) }}$ - The summoned self, the self which is completely for others, the self that becomes the hostage.

How to understand the self in Levinas' philosophy is closely related to how to understand others in Levinas' philosophy, this correlation is like two sides of a coin. Levinas's view of self comes from his strong concern for others, a self that can be there for others, a self that can take absolute responsibility, can be both active and passive Levinas called subject self and object self. Levinas studied the third meditation of Descartes. The result is that the clarity of I think depends on the clarity of a God that above I think. When the self is still in a separate individual state, there is no active freedom. At that time, the self is surrounded by other things, and the self can enjoy other things, in the eyes of Levinas, at

[France] Emmanuel Levinas, English edition translated by Alphonso Lingis. Otherwise than Being or Beyond Essence. [M]. Netherlands, Dordrecht: Kluwer Academic publisher, 1991. this time the self is not true self, or primitive self. God is the absolute other, and everyone is the absolute other like God. It can be said that Levinas raised others to the position of God.

Although the issue of others is almost as old as the issue of self, Western philosophy seems to have neglected the point during the obsession of pursuing self, that is, others are the necessary prerequisite for the formation of self/subjectivity. "The relationship with non-self is prior to any relationship between self and oneself". 5 (P119) Others as the object of understanding are not real others. He-I who are in a relationship are not real others as well. Being together based on ontology can not solve the problems of others. Unlike most rebelliousness against subjectivity, Levinas is transcending the subject from within the subject. Levinas "This work interprets the subject as a hostage and interprets the subjectivity of the subject as an alternative to the nature of existence". ${ }^{6}(\mathrm{P} 2)$

The issue of others is always related to the status of practical philosophy. The issue of others is an issue that does not exist in the solipsism philosophy. Non ontologicalepistemology oriented issues of others. Others are not the object of self/subject understanding, but the only and most important object of relationship, and even the conditions which subjectivity itself can be formed. From which can be seen that the philosophy of Levinas is an alternative, and it is an attempt to subvert the subject from the inside. This kind of attempt is not so much a rebellion, but rather than what Levinas himself said, it is "a defence of subjectivity"."Totality and Infinity" can be seen as a result of this defence. In the book, Levinas starts from the prehistory of the self and examines the formation process of the self, then concluded that the self is highlighted from the existence of anonymity, is diachronic, dynamic, self and time prominent from the existence, infinity and freedom. The subjectivity of ethics exempts the ontological subjectivity of conceptualization, and the latter restores everything to itself. The ethical "I" is the subjectivity in terms of condescending in front of others and sacrificing one's freedom for others' original calls. 6 (P2) This new concept of subject can be seen as a new tendency in contemporary philosophy.

\section{CONCLUSION}

There are many ways to explore the concept of self, and it is one of the exploration from the perspective of others. This means not treating the self as the Ulysses-style departure and return, but treating the self as an Abraham-style eternal alien. The significance of this way of discussion is to re-examine the meaning of difference in the formation of identity. The other's enlightenment on the self not only forms the source of the practice relationship between him and me, but also the reason for the formation of self and the establishment of subjectivity. It is to explore the ultimate purpose of the self through us. Face to Face with Levinas [M]. American, New York: State University by NewYork Press, 1950. 


\section{REFERENCES}

[1] [Ancient Greece] Plato et al.: "Basic Documents of Western Philosophy", translated by Bao Limin, etc. Hangzhou: Zhejiang University Press, 2007.

[2] [German]E.Zeller, Translated by Weng Shaojun. History Outline of Ancient Greek Philosophy. [M]. Jinan: Shandong People's Publishing Press, 1996

[3] [France] Bergson, Translated by Wu Shidong. Time and Free Will. [M]. Beijing: The Commercial Press, 1958.

[4] [France]Emmanuel Levinas, English edition translated by Alphonso Lingis.Otherwise than Being or Beyond Essence .[M]. Netherlands , Dordrecht:Kluwer Academic publisher, 1991.

[5] [France]Emmanuel Levinas, English edited by Richard A.Cohen. Face toFace with Levinas.[M]. American, New York: State University by NewYork Press, 1950.

[6] [German] Martin Buber, translated by Chen Weigang. Me and You. [M]. Beijing: The Commercial Press, 2015.

[7] [Ancient Greece] Plato, translated by Guo Binhe, Zhang Zhuming. Republic [M]. Beijing: The Commercial Press, 1986.

[8] [Ancient Greece] Aristotle, translated by Liao Shenbai. Ethika Nikomachea. [M]. Beijing:The Commercial Press, 2013.

[9] [France] René Descartes, translated by Xu Tao. Meditations on First Philosophy. [M]. Beijing: Jiuzhou Press, 2007.

[10] [English] David Hume, translated by Guan Wenyun. Humanity Theory. [M]. Beijing: The Commercial Press, 2016.

[11] [English] David Hume, translated by Lv Daji. Human Sense Research. [M]. Beijing: The Commercial Press, 1999.

[12] [German] Immanuel Kant, translated by Han Shuifa. Practical rational critique. [M]. Beijing:The Commercial Press, 1999.

[13] [German] Hegel, translated by He Lin, Wang Taiqing. The history of philosophy lecture, volume III. [M]. Beijing:The Commercial Press.2008.

[14] [German] Edmund Husserl, translated by Ni Liangkang. Logic Research Volume 1. [M]. Shanghai: Shanghai TranslationPublishing Company, 2006.

[15] [Germany] Martin Heidegger, translated by Chen Jiaying, Wang Qingjie, proofread by Xiong Wei,revised by Chen Jiaying. ExistenceAnd time. [M]. Beijing: SDX Joint Publishing Company. 2006.

[16] [German] Emmanuel Levinas, translated by Zhu Gang.Totality and Infinity. [M]. Beijing: Peking UniversityPublishing Company, 2016.

[17] [USA] Alasdair McIntyre, translated by Song Jijie. Pursuing virtue. [M]. Nanjing: Yilin Publishing Company. 2003. 